
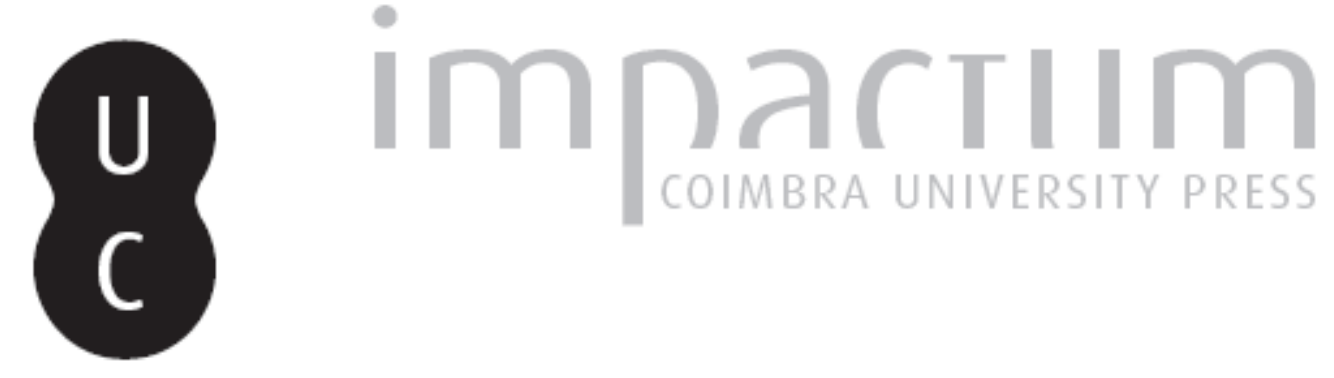

\title{
A comparative analysis of forest fire policies in protected areas in Portugal and in the state of Santa Catarina (Brazil): a general approach
}

Autor(es): $\quad$ Tedim, Fantina; Herrmann, Maria Lúcia de Paula

Publicado por: Associação Portuguesa de Riscos, Prevenção e Segurança

URL

persistente:

URI:http://hdl.handle.net/10316.2/36227

DOI:

DOI:http://dx.doi.org/10.14195/1647-7723_14_7

Accessed : $\quad$ 26-Apr-2023 11:52:47

A navegação consulta e descarregamento dos títulos inseridos nas Bibliotecas Digitais UC Digitalis, UC Pombalina e UC Impactum, pressupõem a aceitação plena e sem reservas dos Termos e Condições de Uso destas Bibliotecas Digitais, disponíveis em https://digitalis.uc.pt/pt-pt/termos.

Conforme exposto nos referidos Termos e Condições de Uso, o descarregamento de títulos de acesso restrito requer uma licença válida de autorização devendo o utilizador aceder ao(s) documento(s) a partir de um endereço de IP da instituição detentora da supramencionada licença.

Ao utilizador é apenas permitido o descarregamento para uso pessoal, pelo que o emprego do(s) título(s) descarregado(s) para outro fim, designadamente comercial, carece de autorização do respetivo autor ou editor da obra.

Na medida em que todas as obras da UC Digitalis se encontram protegidas pelo Código do Direito de Autor e Direitos Conexos e demais legislação aplicável, toda a cópia, parcial ou total, deste documento, nos casos em que é legalmente admitida, deverá conter ou fazer-se acompanhar por este aviso.

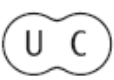




\section{territorium}




\section{A COMPARATIVE ANALYSIS OF FOREST FIRE POLICIES IN PROTECTED AREAS IN PORTUGAL AND IN THE STATE OF SANTA CATARINA (BRAZIL) : A GENERAL APPROACH}

Fantina Tedim *, Maria Lúcia de Paula Hermann** *fpedrosa@letras.up.pt Faculdade de Letras, Universidade do Porto

**herrmanmacfh.ufsc.br

Departamento de Geociências, Universidade Federal de Santa Catarina (UFSC)

\section{RESUMO}

Dados recentes sugerem que Portugal e Brasil têm visto um aumento no número de incêndios florestais emáreas protegidas. Em Portugal, entre 1992 e 2003 a média amual de área ardida em áreas protegidas foi de 10418 ha e no períodb 2001-2005 de 16025 ha. No Brasil, todavia, o Estado de Santa Catarina apresentau um decréscimo no número de incêndios. Combase nestes factos, os dojectivos principais da presente investigação são: analisar a incidência, a severidade e as causas dos incêndios florestais em áreas protegidas em ambos os Estados e estudar os impactos das políticas de prevenção e combate, bem como as estratégias e modelos implementados na recuperação das áreas ardidas.

Palavras chave: áreas protegidas, risco de incêndio florestal, áreas ardidas.

\section{ABSTRACT}

Recent data suggest that both Portugal and Brazil have seen an increase in the number of forest fires in protected areas. In Portugal, between 1992 and 2003 the anmul average area bumed in protected areas was 10,418 ha and in the period 2001-2005 was 16, 025 ha. Nevertheless, in Brazil, the state of Santa Catarina stands at as the state recording a decrease in the number of fires. Based on these facts, the main dojectives of the present research are to analyse the incidence, severity and causes of forest fires in protected areas in both countries and to assess the impacts of prevention and combat policies as well as the strategies and models implemented in the recovery of loumed areas.

Key words: protected areas, wildfire hazard, bumed areas.

\section{RÉSUMÉ}

Domées récentes montrent que le Portugal et le Brésil ont vu augnenter le nonbre des incendies de forêt dans les aires protégées. Au Portugal, entre 1992 et 2003, la moyenne amuelle d' aire brûllée dans les aires protégées a été de 10418 ha et entre 2001 et 2005 de 16025 ha. Pourtant, au Brésil, l'état de Santa Catarina a enregistré une diminution du nombre d' incendies. Devant ces faits, les dojectifs principaux de cette recherdhe sant l' analyse de l'incidence, sévérité et causes des incendies de forêt dans les aires protégés des deux pays et l'étude des conséquences des politiques de prévention et combat ainsi que les stratégies et modèles développées parr la récupération des aires brîlées.

Mbts clé : aires protégées, risque d' incendie de fôret, aires brûlées. 


\section{Introduction}

Protected areas are designed for the protection and maintenance of the ecological diversity and the natural and oiltural resarces featured in these areas through legal or other effective means. However, the forest fires which rearrently affect these areas cauld contribute to the degradation of the landscape, the destnuction of their ecosystems and to a change in terms of their ecological and economic value. In adbition to these consequences, forest fires contribute to gldbal warming due to greenhouse gas emissions. Brazil, for instance, contributes with 3\% of the total greenhouse gas emissions according to the parameters of the Kyoto Protocol (Pereira et al., 2004) and at of this, 65\% come from deforestation and forest fires ${ }^{1}$.

Despite all prevention and suppression measures implemented over the last few years, recent data suggest that both Portugal ${ }^{2}$ and Brazil have seen an increase in thenmber of forest fires inprotectedareas. Based on these facts the main dojectives of the present paper are: analyse the incidence, severity and causes of forest fires inprotected areas in Portugal andBrazil, characterised by different geographic and cultural realities; assess the impacts of prevention and suppression policies as well as the strategies and models implemented in the recovery of bumed areas. Given the larger extension of the Brazilian territory when compared to Portugal, we opted for taking into consideration in this study only the state of Santa Catarina ${ }^{3}$.

The National Network of Protected Areas in Portugal is constituted by protected areas of national interest comprising the categories of national park, natural reserve, natural park, natural monument, and also by protected areas of regional or local interest designated protected landscapes. There are also private protected areas, which are commonly named «sites of biological interesto.

In Brazil nature conservation units are divided into Integral Protection Conservation Units and Sustainable Use Conservation Units. Integral Protection Conservation Units include the categories of Ecological Station, Biological Reserve, Park, Natural Monument and Wil cllife Refuge. These aimbasically at pronoting nature conservation while allowing the indirect use of the units' natural resourcest. The Sustainable Use Conservation Units are designed to combine nature conservation with the direct use of part of the units' natural resarrces. This group includes Envircomental ProtectedArea, Relevant Ecological Interest Reserve, National Forest, Extractive Reserve, Fauna Reserve, Sustainable Development Reserve, Private Natural Heritage Reserve. In the State of Santa Catarina there are 14 federal conservation units (Table 1) and 9 state conservation units (Table 2 ) .

A questionnaire was sent out by e-mail to all protected areas of both countries, except areas constituted exclusively by marine reserves. The questionnaire wes stnuctured in 5 sections: dimension and causes of forest fires, firepreventionmeasures, fire surveillance, fire suppression and recovery of lomed areas, amounting to a total of 50 questions.

In portugal a total of 28 questionnaires were sent to all parks, protected landscapes and natural reserves ${ }^{5}$ (Table 3); we have excluded from this study the

Table 1 - Total Number of Federal Conservation Units in the State of Santa Catarina.

\begin{tabular}{|c|c|c|}
\hline Conservation Unit & Area (ha) & Establishment Date \\
\hline Mata Preta Ecological Station(4) & & \\
\hline Carijó Ecological Station (2) & 712 & Decree n. 94.656/87 \\
\hline Serra do Itajai National Park & $57,475.00$ & Decree 04/06/2004 \\
\hline Säo Joaquim National Park & $42,837.00$ & Decree n. 50.922/61 \\
\hline Araucárias National Park (3) & $12,841.00$ & Decree 19/10/2005 \\
\hline Arvoredo Maritime Biological Reserve (1) & $17,600.00$ & Decree n. $99.142 / 90$ \\
\hline Anhatomirim Environmental Protection Area (1) & $3,000.00$ & Decree n. 528/92 \\
\hline Baleia Franca Environmental Protection Area (1) & $156,100.00$ & Decree n. 14/09/2000 \\
\hline Serras das Abelhas e Rio da Prata Relevant Ecological Interest Reserve & $5,025.00$ & Decree 005/90 \\
\hline Caçador National Forest & 710.44 & Implementing Order n. 560/68 \\
\hline Chapecó National Forest & $1,606.00$ & Implementing Order $560 / 68$ \\
\hline Ibirama National Forest & 570.58 & Decree n. $95.818 / 88$ \\
\hline Três Barras National Forest & $4,458.00$ & Implementing Order n. 560/1968. \\
\hline Pirajubaé Maritime Extractive Reserve (1) & $1,444.00$ & Decree n. 533/92 \\
\hline Total & $304,379.02$ & \\
\hline
\end{tabular}

Sarrce: IBAMA - Instituto Brasileiro do Meio Ambiente e das Rearrsos Naturais Renováveis (Brazilian Institute of Envirament and Renewable Natural Resaurces) , 2006.

\footnotetext{
${ }^{1}$ According to the Envircmental Research Institute of Anazonia carbon dioxide emissions resulting from deforestation and forest fires in Amazonia amount to more than the dable of the enissions de to thebuming of fossil fiels in the entire cauntry. 20 millian tans of carbon dioxide are released annully into the atmosphere from the buming of fossil fivels, while forest fires and deforestation release 95 milliontons.

${ }^{2}$ We cnly included in this paper protected areas in mainland Portugal.

${ }^{3}$ The area of the State of Santa Catarina is $95,985 \mathrm{~km} 2$, whereas the area of mainland Portugal is $88,500 \mathrm{~km}^{2}$.
}

(1) Not included in the study because this is amarine conservation unit; (2) This is a mangrove area; (3) Although the unit has retumed the questionaire, it has not been considered as the unit was only established in 2005 and is yet to record a forest fire; (4) Nb data available;

${ }^{4}$ Except for the cases laid down in the National System of Conservation Units.

${ }^{5}$ We didnot include in ar analysis the Berlengas Natural Reserve, since this isanisland. 
remaining protected areas, since they are in principle less vilnerable to forest fires. Only 15 questionaires were retumed, representing a coverage ratio of $54 \%$. Still, the retumed questionaires represent 83\% of the number of forest fires and $94 \%$ of the total bumed area, thus we can consider the sample as significant. The response from the conservation units of the State of Santa Catarina was extraordinary, since all state and federal units retumed the questionaire amanting to a total of 17 questionnaires ${ }^{6}$.

Table 2 - Total Number of State Conservation Units - State of Santa Catarina.

\begin{tabular}{|c|c|c|}
\hline Conservation Unit & Area (ha) & Decree/Established \\
\hline Serra do Tabuleiro State Park & $87,405.00$ & Decree n. 1.260/75 \\
\hline Serra Furada State Park & $1,329.00$ & Decree n. 11.233/80 \\
\hline Sassafrás State Biological Reserve & $5,223.00$ & Decree n. 2.221/777 \\
\hline Canela Preta State Biological Reserve & $1,899.00$ & Decrees $11.232 / 80$ \\
\hline Aguai State Biological Reserve & $7,672.00$ & Decree n. 19.635/83 \\
\hline Araucárias State Park & 612 & Decree n. 293/03, \\
\hline Fritz Plaumann State Park & 740 & Decree n. 797/03 \\
\hline Rio Canoas State Park & $1,200.00$ & Decree n. 1.871/04 \\
\hline Acarai State Park & $6,667.00$ & Decree 3.517/05 \\
\hline Total & $112,747.00$ & \\
\hline
\end{tabular}

Sarrce: IBAMA - Instituto Brasileiro do Meio Anbiente e dos Rearrsos Naturais Renováveis (Brazilian Institute of Environment and Renewable Natural Resarraes) , 2006.

Table 3 - Identification of the protected areas in Portugal which have retumed the questionaire

\section{The incidence of forest fires in protected areas in Portugal and SantaCatarina}

Forest fires are a severe problem that has been affecting Portugal over the last few decades, including the protected areas, which have seen the situation becomemore seriaus since the number of forest fires in protected areas has increased considerably since 1992. The maximum number of occurrences was reached in1998 and 20007 (Figure 1). The years 2003 and 2005 presented the largest lamed area recording $28,272.90$ ha and 20,432.44 ha, respectively (MAOIDR, 2006). Between 1992 and 2005 the anmual average area loumed was 10,418 ha and in the period 2001-2005 about 16, 025 ha.

In 2005, according to the Portuguese Forest Service, the total forest area bumed amounted to 325,226 ha in the Portuguese territory corresponding to a rate of $3.65 \%$. This figure is slightly higher then the $3.19 \%$ rate recorded in that same year by the Portuguese Network of Protected Areas (ICN, 2006), which is nonetheless worrying, since protected areas are intended for the safeguard and conservation of the ecological diversity and the natural and cultural resarrces. The consequences in terms of biodiversity loss are not generally assessed, lat they are certainly important, since in 2005, for instance, 35\% of the area bumed was identified as Priority Area for Nature conservation.

\begin{tabular}{|c|c|c|}
\hline Protected Area & Area (ha) & Establishment Date \\
\hline Peneda-Gerês National Park & $69,592.50$ & Law Decree n. 187/71 \\
\hline Alvão Natural Park ${ }^{*}$ & $7,202.66$ & Law Decree n. $237 / 83$ \\
\hline Vale do Guadiana Natural Park & $69,669.30$ & Reg. Decree n. 28/95 \\
\hline Serras d'Aire e Candeeiros Natural Park & $38,392.53$ & Law Decree n. $118 / 79$ \\
\hline Serra de São Mamede Natural Park & $56,058.87$ & Law Decree n. 121/89 \\
\hline Sudoeste Alentejano e Costa Vicentina Natural Park ${ }^{\star}$ & $60,485.05$ & Law Decree n. 241/88 \\
\hline Sintra-Cascais Natural Park ${ }^{\star}$ & $14,450.85$ & Law Decree n. $292 / 81$ \\
\hline Montesinho Natural Park & $74,544.62$ & Law Decree n. $355 / 79$ \\
\hline Litoral Norte Natural Park* & $1,316.64$ & Law Decree n. 357/87, \\
\hline Ria Formosa Natural Park & $17,900.92$ & Law Decree n. $45 / 78$ \\
\hline Serra da Estrela Natural Park & $99,478.05$ & Law Decree n. 557/76, \\
\hline Arrábida Natural Park ${ }^{*}$ & $11,054.74$ & Law Decree n. 622/76 \\
\hline Douro Internacional Natural Park & $87,011.26$ & Law Decree n. $8 / 98$ \\
\hline Tejo Internacional Natural Park & $23,728.05$ & Reg. Decree n. $9 / 00$ \\
\hline Serra do Açor Protected Landscape * & 373.40 & Law Decree n. $67 / 82$ \\
\hline Serra de Montejunto Protected Landscape & 4,5 & Reg. Decree n. 11/99 \\
\hline Albufeira do Azibo Protected Landscape* & 4,897 & Reg. Decree n. 13/99 \\
\hline Corno do Bico Protected Landscape & 2,175 & Reg. Decree n. 21/99 \\
\hline Lagoas de Bertiandos e São Pedro dos Arcos Protected Landscape & 346 & Reg. Decree n. 19/00 \\
\hline Arriba Fóssil da Costa da Caparica Protected Landscape & $1,551.50$ & Law Decree n. 164/84 \\
\hline Sapal de Castro Marim e Vila Real de Santo António Natural Reserve * & 2,312 & Law Decree n. 162/75 \\
\hline Estuário do Tejo Natural Reserve ${ }^{\star}$ & $9,846,48$ & Law Decree n. $565 / 76$ \\
\hline Dunas de São Jacinto Natural Reserve ${ }^{\star}$ & 733.52 & Law Decree n. 41/79 \\
\hline Paul do Boquilobo Natural Reserve & 817.62 & Law Decree n. 198/80 \\
\hline Estuário do Sado Natural Reserve* & $17,206.06$ & Law Decree n. $430 / 80$ \\
\hline Serra da Malcata Natural Reserve* & $16,158.66$ & Law Decree n. 294/81 \\
\hline Paul de Arzila Natural Reserve* & 586,76 & Law Decree n. $219 / 88$ \\
\hline Lagoas de Santo André e da Sancha Natural Reserve & $3,123.39$ & Reg. Decree n. 10/00 \\
\hline
\end{tabular}

*So far this protected area has not retumed the questionaire.

${ }^{6}$ However, the sample will consider only 16 conservation units, since the Araucárias National Park was only established in 2005 and has no records efforestires.
${ }^{7}$ The data regarding 2006 forest fires is yet to be validated by the Institute for Nature conservation and therefore it is still not available. 


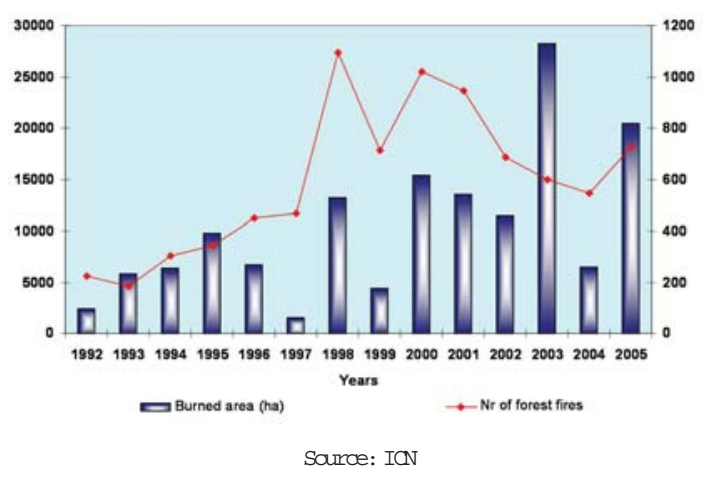

Fig. 1 - Evolution in the number of forest fires and loumed area in Protected Areas in Portugal.

Although the concem with the protection of the natural heritage against fire arose effectively with the establishment of protected areas, the results of the questionnaire show us that in most of the protected areas the largest fires to affect them ocaurred after 2000 (Table 4) . We should point at that in the natural parks of Montesinho, Douro Intemacional and Serra da Estrela the anulal average area bumed is higher than 1,000 ha. If we consider the loumed area in the Peneda Geres National Park in 2006, which constitutes so far the year with the highest rate, the averagelomed area since 1992 is also higher than 1,000 ha (1,109ha) .

The data available conceming the causes of fires in protected areas are inconclusive, since the great majority of ocaurrences were not investigated or the results of the investigation were inconclusive. However, it is clear that the cases of forest fires are clearly hman, such as accident, negligence and arson.

In Brazil the number of forest fires in protected areas ${ }^{8}$ has increased significantly from 1, 754 fires in

Table 4 - Largest Fires, per year of ocarrrence, in Portugal.

\begin{tabular}{|c|c|c|c|}
\hline Protected area & Year(1) & $\begin{array}{l}\text { Area(1) } \\
\text { (ha) }\end{array}$ & $\begin{array}{c}\text { Average Area Burned } \\
(1992-2005)(2)\end{array}$ \\
\hline Serra de S. Mamede Natural Park & 2003 & 13,35 & 815 \\
\hline Douro Internacional Natural Park & 2003 & 1,3 & 1,306 \\
\hline Serra da Estrela Natural Park & 2005 & 4,772 & 4,178 \\
\hline Penedo-Gerês National Park & 2006 & 3,945 & 763 \\
\hline $\begin{array}{c}\text { Serras d'Aire e Candeeiros Natural } \\
\text { Park }\end{array}$ & 2006 & 2,997 & 879 \\
\hline Montesinho Natural Park & 1998 & $1,185.51$ & 1,529 \\
\hline Vale do Guadiana Natural Park & 2003 & 1 & 318 \\
\hline Ria Formosa Natural Park & 2004 & 173 & 31 \\
\hline Tejo Internacional Natural Park & 2002 & 293,2 & 48 \\
\hline Corno do Bico Protected Landscape & 2006 & 150 & No data* \\
\hline $\begin{array}{l}\text { Lagoas de Bertiandos e São Pedro } \\
\text { dos Arcos Protected Landscape }\end{array}$ & . & 0 & 0 \\
\hline $\begin{array}{l}\text { Arriba Fóssil da Costa da Caparica } \\
\text { Protected landscape }\end{array}$ & 1996 & 65 & 9 \\
\hline $\begin{array}{l}\text { Serra de Montejunto Protected } \\
\text { Landscape }\end{array}$ & 2003 & 2.23 & No data* \\
\hline Paul do Boquilobo Natural Reserve & 2003 & 12.8 & 1 \\
\hline $\begin{array}{c}\text { Lagoas de Santo André e da Sancha } \\
\text { Natural Reserve }\end{array}$ & 2006 & 0.006 & 0.5 \\
\hline
\end{tabular}

Sarrce: (1) Survey, 2007; (2) Institute for Nature Conservation, 2006. *Asprotected areas of regional interest, the fires that ocar here are not recorded since these areas are not managed by the Institute for Nature Conservation

${ }^{8}$ Based an a sample of approximately $50 \%$ of the Brazilian states (Santos et al., 2006). the period 1983-1987 to 19, 337 between 1998 and 2002 (Santos et al. , 2006). The data supplied by IBAMA also support this analysis, with 2002 and 2003 recording high levels of lamed area, even though the highest levels have been recorded in 1994 (Figure 2) . Over that period the State of Santa Catarina, with a total area of $95,985 \mathrm{~km}^{2}$ corresponding to $1.12 \%$ of the Brazilian territory, has not only been the Brazilian state that recorded a decrease in the number of forest fires, but also the state with the smaller number of occurrences, decreasing from 36 in the 1980s to 22 between 1998 and 2002, which corresponds to $0.11 \%$ of fires inprotected areas inall Brazilianstates.

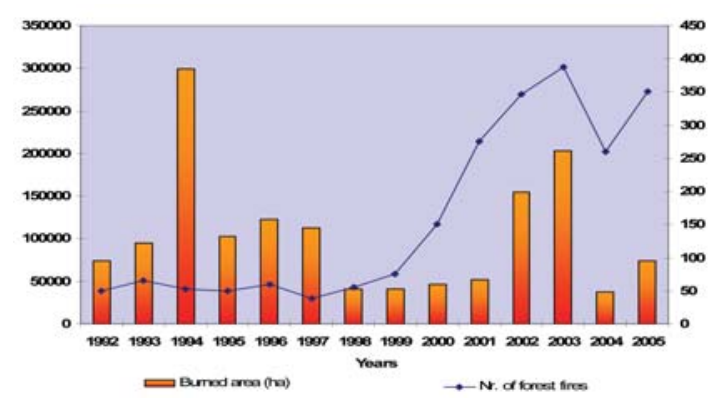

Sarrce: IBAMA - Instituto Brasileiro do Meio Ambiente e das Rearrsos Naturais Renováveis (Brazilian Institute of Envirarment and Reneweble Natural Resarrces) , 2006.

Fig. 2 - Evolution in the number of forest fires in State Conservation Units in Brazil.

In the state of Santa Catarina at of the conservation units under study recorded fire occurrences; among these we should point out the Três Barras National Park with 12 occurrences, which affected areas between 1 and 13 hectares with pine vegetation and agriaultural lands and Serra do Tabuleiro State Park, the largest conservation unit of the state, comprising 1\% of the state's territory, with 3 ocarrences, which affected approximately 4 ha of herbaceaus vegetation. Among the probable causes we should point at pasture renovation, followed by unknown causes and arson.

Inbalance, the incidence of forest fires inprotected areas in Portugal and Santa Catarina is very different but we should point out an important interamual change. Still, we were able to identify conmon causes as in both case-studies the human causes are predominant.

\section{The prevention of forest fires in protected areas}

From the answers to the questionnaire it becomes clear that all protected areas in Portugal adknowledge the existence of a policy of protection of forests against fire which includes prevention and surveillance measures as theirmainpriorities. The active participation of the protected areas in fire suppressionisnot so evident since 
onlynine of the protectedareas have initial attadk teams properly equipped. This is definitely the weak link as far as the recovery of bumed areas is concemed as little attention is paid to this in theprotection of forests.

The management of protected areas of national interest in Portugel is a competency of the Institute for Nature Conservation (ICN) ${ }^{9}$. The Institute established in its report for 2005 the following topics as the main priorities interns of theprotection of the forests against fire: decrease the lamed area, especially in priority areas for nature conservation as the most valuable ecological areas, reduce thenumber of ignitions, reduce the vulnerability of these areas and, finally, monitor and restore bumed areas. These objectives are effectively acknowledged as priorities by protected areas (Table 5), which also aim at improving suppression efficacy and promoting a more effective organisation process.

Table 5 - abjectives of the forest fire policy in Portugal.

\begin{tabular}{|c|c|c|}
\hline & Number & $\%$ \\
\hline Decrease burned area & 11 & 73 \\
\hline Reduce number of ignitions & 10 & 66 \\
\hline Reduce vulnerability of the areas & 9 & 60 \\
\hline Increase resilience of forest & 9 & 60 \\
\hline Improve efficacy of suppression & 9 & 60 \\
\hline Promote a more effective organisation process & 8 & 53 \\
\hline Restore burned areas & 6 & 40 \\
\hline Did not answer & 1 & 7 \\
\hline Sarce: Srrvey, 2007.
\end{tabular}

It is generally believed that there have been improvements in forest fire prevention over the last few years, especially due to the availability of a greater number of surveillance and detection means. In fact, we should emphasise a greater awareness and cormitment of public and private institutions in promoting a greater surveillance effort, especially throughmobile teams, and providing them with better training and equipment, resulting in a persuasive and pedagogical action in removing the possible causes of forest fires (Table6) .

There is also a closer collaboration between the entities involved in fire prevention and consequently a better coordination of the means and humen resources. This collaboration involves not only several public institutions and civil protection agents, lat alsomany private entities. Anong the latter, we should point at entities such as scout associations, hunting associations, fishermen's associations, foresters associations, farmer associations, envirormental associations, common landmanagers, all terrain clubs. Thus, it is possible to conclude that there is a considerable participation of Community Based organisations in forest fireprevention.

${ }^{9}$ In 2007 the IdN - Instituto de Conservação da Natureza (Nature Conservation Institute) was renamed ICBN - Instituto da Conservação da Natureza e da Biodiversidade (Nature andBiodiversity Conservation Institute) - (Decree-Law No. 136/2007, DR No. 82, Series I, April 27th 2007.

Table 6 - Prevention measures.
\begin{tabular}{|c|c|c|}
\hline Prevention measures & Number & $\%$ \\
\hline Land Mobile Surveillance & 15 & 100 \\
\hline Risk Areas Identification & 14 & 93 \\
\hline Fuel Removal & 9 & 60 \\
\hline Education and Awareness Campaigns & 9 & 60 \\
\hline Construction of water points & 8 & 53 \\
\hline Track Construction and Improvement & 8 & 53 \\
\hline Forest Management & 7 & 47 \\
\hline Definition and Maintenance of Buffer Zones & 6 & 40 \\
\hline Preventive siviculture & 6 & 40 \\
\hline Land Fixed Surveillance & 6 & 40 \\
\hline Use of Prescribed Burning & 3 & 27 \\
\hline Clearance for using Prescribed Burning & 4 & 20 \\
\hline Fire Hazard Information & 2 & 13 \\
\hline Information Signs & 1 & 7 \\
\hline Restricted Access by cars to high risk areas & 1 & 7 \\
\hline Purchase of communication equipment & 1 & 7 \\
\hline Removal of barbecues from picnic parks & 1 & 7 \\
\hline Contact with shepherds & 1 & 7 \\
\hline Saurce: Survey, 2007. & & \\
\hline
\end{tabular}

Other factors such as changes to legislation, namely as far as the control of offences is concemed, have also been considered positive. The respondents have also indicated two other factors which are considered important, yet not effective enogh: 1) forest management, both in terms of fuel removal and the doice for fire resistant plant species, which is a measure of partiaularly difficult implementation. The use of prescribed fire was only mentioned by the natural parks of Montesinho, Peneda-Gerês and Serra de Aire e Candeeiros. This practice is designed to meet specific objectives, especially pasture renovation and not so much in terms of fuel removal; however, this is not a general practice possibly due to limitations not so much technical but at the level of human resarrces; 2) the awareness of the local commuities to fuel removal andreduction of potential fire riskbehaviar is still not a widespread concem among Portuguese protected areas. Arrently, public education relies heavily on making information available to people. However the fact that simply providing people with information is not sufficient to encourage preparedness, because pecple do not necessarily accept this information at face value. Rather, it is howpeople intenpret their risk and the information available that determines whether they prepare for forest fires. While some people appear predisposed to prepare, but need to be guided in this endeavour, others decide not to prepare. This means that, whenplaming public education, it is not enaugh to know that levels of preparedness are low. It becomes necessary to find at if levels are low because people have decided not to prepare, or if levels are low because people need guidance to know what to do. The education campaigns should be directed at the general audience but also to specific groups such as shepherds.

The Portuguese fire prevention system is qualified by the majority of the Portuguese protected areas as good. Only the Douro Intemacional Natural Park, the Tejo Intemacional Natural Park, the Paul do Boquildoo Natural Reserve and the Ria Formosa Natural Park believe the system could be improved. 
In the State of Santa Catarina only the São Joaquim National Park and the National Forests Três Barras and Caçador and the Serra do Tabuleiro State Park have adopted policies of protection of forests against fire, implemented respectively in 2004, with the establishment of the unit, in 2005 and 1992 with the establishment of the Enviromental Military Police. These policies foous on prevention, surveillance and alert measures and the main dojectives of the policy are the reduction of vilnerabi i ity to the deflagration of forest fires. The core measures adopted in terms of prevention in Santa Catarina include the identification of risk prone areas, the construction or opening of intemal and extemal buffer zones; the use of prescribed fire, the purchase of specific equipment for fire suppression; purchase of surveillance vehicles; the promotion of education and awareness campaigns and information to the population about fire risk through the media, especially intended at the resident owners in conservation units. The level of efficiency attributed to the prevention system was acceptable and prevention measures in federal conservation units are funded by PREVFOGO ${ }^{10}$. At the state level we should point out the resource to projects financed by the Bank for Reconstruction and Development - IBRD ${ }^{11}$ and the German Development Bank - KFW Bankengruppe ${ }^{12}$.

Inprotection of forests against fire there has been established a good cooperation between public and private entities, suchas Civil Defence andFrviromental ProtectionMi litary Police, although a lot can still be done as far as the involvement of the local commuity is concemed. Among the farr conservation units which have adopted a policy of protection of forests against fire, three answered that fire prevention has improved over the last years due to: stricter envirormental legislation, greaterefficacy of the fire-fighters, agreater awareness of the population and their past experience dealing with fires and the instnuctions andmaterial given the staff of theprotected areas.

There is an important difference between the Portuguese and Brazi 7 ian real ity in terms of protected areas with implications onprotection of forests against fire and wich is intimately related with land ownership. Whereas in Brazil the entire area of the conservation units is state owned land, in Portugal most land is

\footnotetext{
${ }^{10}$ PREVFOCO was established in Brazil in 1989 as the National System for Wildfire Prevention and Suppression (Decreen. 97 635). In 2001 (Decree n. 3833) it is transformed in National centre of Forest Fire Prevention and Suppression. Its range of action includes controll ing prescribed buming and pronoting activities of forest fire prevention and suppression in conservation units. Arrently Prevfogo is developing prevention and suppression activities in 78 conservationunits.

The AREVFOCO together with the National Institute for Space Research (INEE) implemented in 1990 the manitoring and control of fires in Brazil using the satellites NOAA, Land Sat spot.

${ }^{11}$ Micro-Bacia Projects.
}

${ }^{12}$ Project for the Protection of the Atlantic Forest. privateproperty. However, this real ity varies according to the protected area. For example, in the Peneda-cerês National Park, land ownership is distributed intopublic land (approximately 3\% of the territory), common lands (79\%) and private property (17\%) .

\section{Fire Detection and Supression}

Surveillance plays a vital role in the reduction of ignitions andlarmed area. There is a general consensus about the recent improvement of surveillance in Portugal, since besides fixed surveillance (in lookat towers) whichstill remains active insix of the protected areas, mobile survei l lance has evolved tremendously. This type of surveillance is highly effective inctissuading possible criminal actions, but is also pedagogically efficient as it alerts the populations to risk behaviar. Surveillance teams are constituted by staff of the protected area, members of the Portuguese Republican National Guard, fire-fighters and brigades of "sapadores florestais" (forest guards). In the PenedaGerês National Park, for instance, twelve teams of "sapadores florestais" were established by the managers of common lands and foresters associations and are in charge of the survei l lance of the park. Only the Serra de Montejunto Protected Landscape has access to video surveillance.

All the effort put in the constitution, equipment and training of these survei llance teams explains the opinion of nine of the protected areas that their survei l lance system is effective. The remaining bel ieve their system to be "acceptable", although they have the opinion it is possible to improve the system, inpartiallar because they do not have a number of surveillance teams adequate to the fire risk of the area, or still because it is necessary to provide the brigades with better training and equipment. Since the decrease of the loumed area is intimately related witha fast, effective initial attadk, in some protected areas survei l lance teams are also equipped witha first interventionkit.

While some of the protected areas cant with initial attack teams equipped with varied resources such as booster units or even a backhoe, other protected areas depend completely upon extemal means to suppress thefires.

These initial attadk teams are generally very effective because they are highly trained, extremely professional experts, who keep regularly updated on the latest techniques; in addition, most of the staff possesses already practical experience. Nevertheless, some protected areas mentioned that their teams are constituted by seasonal staff, which reduces significantly the efficacy of the team, since it wouldbe desirable to cant with full-time staff menbers topranote greater stabi lity as well as regular training actions. 
Mbst protected areas bel ieve that the suppression has improved over the last few years thanks to a more effective action by initial attadk teams, to a better coordination of suppression, to the availability of more means and to better fire-fighter training. However, there are still negative aspects that need to be overcome such as the ladk of knowledge of the territory and the existing infrastnutures (tradks, waterpoints) , excessive use of water or the choice of other suppression techniques by the staff member in charge of the aperations. There has been also mentioned that mopup is sometimes deficiently handled promoting reigritions.

In the state of Santa Catarina only two conservation units count with the help of fire detection systems, promoting local monitoring through land mobile surveillance; other two are equipped with aerial and satellite monitoring. According to the conservation units, the efficacy of surveillance actions has increased. Survei llance missions are carried at by staff menbers of the conservation units and of the envirormental police, lat ctherentities, for instancefire-fighters, amed forces, private companies, may also join the missions. Mast conservation units are of the qpinion that fire detection has not improved over the last fewyears. The main factors explaining this are staff ats, ladk of a fire suppression policy and lack of implementation of proposals aimed at fire suppression. The conservation unit that has adopted PREVFOGO has a considerably more effective fire detection system and a more efficient suppression.

\section{The recovery of bumed areas: arrent situation}

In Portugel the monitoring and recovery of lumed areas is one of the dojectives set out in the policy implemented by the Institute for Nature Conservation. According to the records that have been so far analysed, the first intervention was carried at in the Arriba Fóssil da Costa da Caparica Protected Landscape, which was established in May 1984. This intervention followed a fire that larmed $115 \mathrm{ha}$ of state owned forest land. At that time a recovery project was prepared by the protected area. New plans were drawn to the bumed area. Changes were introduced to the orientation and width of louffer zones and stone pines were planted (PArpsa, 2007) .

In $1989^{13}$ the Portuguese govermment established for the first time the need to ensure the management of bumed areas through specific nules. However, the need to implement this policy has been so far disregarded. conceming this policy, it is possible to sumarise the different procedures adopted by the protected areas in the following topics:

\footnotetext{
${ }^{13}$ Law Decree n. $180 / 89$ of 30 May.
}

- Five of the protected areas declared to have implemented the recovery procedres right after a large fire, although with different motivations: recover the forest, native or of highecological value; minimise the effects of erosion andprovide shelter and food to several fauna groups. New recovery experiences are taking place after the 2003 fires as it happened in the Douro Internacional Natural Park and the Serra de São Mamede Natural Park in which the area burned amounted to 1, 300 ha and 13, 350 ha respectively;

- four of the protected areas already have experience in the recovery of bumed areas resulting froman intervention carried at by the Portuguese Forest Service. The Service is in charge of managing the lands owned by the Portuguese State and the cormon lands under public management regime. However, in a few cases, the common lands are managed directly by each of the protected areas ${ }^{14}$.

- farr of the protected areas declared that they did not have any type of intervention plamed for the recovery of lamed areas; one of them shows no interest carrying at recovery actions;

- the Lagoas de Bertiandos e S. Pedro de Arcos ProtectedArea foreses in itspolicy of forest protection against fire the recovery of lumed areas, lat since its establisment no forest fire has hit the protected area, thus it was not possible for them to answer the topic of recovery of loumed areas.

The intervention inlumed areas aims fundamentally at controlling erosion (4 answers), restoring the forest (4 answers), preventive silviaulture (3 answers) and harvesting bumed timber (2 answers) .

By mentioning the recovery of bumed areas, we are not advocating the compulsory artificial recovery of these areas, but the possibility of after a fire monitoring the areas affected and take advantage of themandimprove their resilience to forest fires, ensuring its economic, ecological, enviromental (for instance, carbon sequestration) and recreative value. The choice for mechanical means should just be taken in cases clearly identified and based on a strategy clearly defined and only when natural regeneration is not doable or when there is a clear need to perform darges invegetation in order topranote its restoration.

There is widespread consensus regarding the advantages of the natural regeneration in the recovery of lumed areas (Table 7) and a great concem with the renoval of invasive species. Reforestationactions using species of higher enviramental value are less prevalent.

The implementation of recovery measures is funded either by public loudget or Erropean Union funds and there are several diffialties of structural, political, organisational, tednical andscientific nature involved in the recovery of loumed areas.

\footnotetext{
${ }^{14}$ Joint Order from the Ministries of Plaming and Territory Administration and Agriaulture, Fisheries and Food fromAugust 20th 1986, DRNb. 202, Series II, September 3rd 1986, p. 8245
} 
One of themain difficilties stems from the fact that most of land is private and divided in small properties; to this we can add the ladk of organisation of Portuguese foresters and the incapacity of many landowners to properly promote the social, environmental and economic value of the nural world by choosing not to invest in their own lands. The insufficiencies of the Portuguese forest land register complicate the contact and negotiation with private landowners.

Mbst forest lands included in the protected areas are private, thus the recovery of bumed areas is the

Table 7 - Recovery techniques.

\begin{tabular}{|c|c|}
\hline Techniques & Nr. of cases \\
\hline Natural regeneration & 7 \\
\hline Control of natural regeneration removing invasive species & 4 \\
\hline $\begin{array}{c}\text { Improve natural regeneration using species of high } \\
\text { economic value }\end{array}$ & 1 \\
\hline $\begin{array}{c}\text { Improve natural regeneration using species of high } \\
\text { environmental value }\end{array}$ & 4 \\
\hline Reforestation using species of high economic value & 2 \\
\hline Reforestation using species of high environmental value & 5 \\
\hline Establishment of permanent pastures & 1 \\
\hline
\end{tabular}

Sarce: Survey 2007.

responsibility of the land owners; inpublic and comm lands the recovery is in most cases a competency of the National Forest Service. In such cases, theprotected area is only responsible for issuing an opinion with regard to the actions which these entities intend to cany at. With regard to this we should point at the ladk of coordination between the entities with the dojective of envisaging the best strategy of intervention in the bumed areas.

Other difficulties concem the lack of human and financial resarces, the extensive cattle breeding and the lack of bush and tree species on the Portuguese makket.

The monitoring of loumed areas is not considered apriority action and it is the competency of the Conselho Nacional de Reflorestação (National Reforestation cancil) to set at the general strategic guidelines for the recovery of lamedareas, respecting the dojectives and prevailing functions of the forest spaces. The guidelines of the National Reforestation Council specifically for the protected areas include assessing the capacity of natural regeneration of the areas hit by fires, followed, complementarily and whenever necessary, by the restoration of the nativeplant species and the control of the invasive exoticplants (Conseltho Nacional de Reflorestação, 2005) .

The National Plan of Forest Protection Against Fire ${ }^{15}$ includes the recovery and restoration of ecosystens as one of its priorities. Its core dojective is the assessment and mitigation of the impacts caused by fire and the implementation of long-term restoration

${ }^{15}$ Cancil of Ministers n. 65/2006 of 26 May. strategies. It is clearly statedin the Plan that the recovery of loumed areas should aim at the future increase of resilience $e^{16}$.

In the State of Santa Catarina none of the conservation units pronote the recovery of the lamed areas. There is a clear choice for the natural recovery of the bumed areas. With the establishment of the militarypolice, in the Serrado Tabuleiro National Park offenders have been identified with the help of thepoblic prosecutors. The offenders have been charged with civil and procedure actions and have to repair the enviramental damage inflicted.

In balance, we can say that the recovery of lumed areas and its monitoring is still of little significance, however they should be understood as an opportunity to re-organise the nural landscape increasing their social, economic and enviromental value, but always bearing in mind the strategies of forest protection against fire.

\section{Conclusion}

The incidence and severity of forest fires in protected areas in Portugal and Santa Catarina are verycifferent. In Portuggl it constitutes aseriasproblem which has worsened in the first years of the 2000s, suggesting the need to have thorough understanding of the causes and the real effectiveness of the measures set at in theplan of forest protectionagainst fire. In the state of Santa Catarina, despite the low record of fires the results of the questionaires in the conservationunits reveal a great concem with possible ocarrences and in this sense themanagers claima greater participation of the goverment and the society in looking for solutions in the area of fire prevention and suppression.

In both cauntries the causes of most part of fires remain unknown, either because no investigation is conducted or because the result of the investigation is inconclusive. In order to achieve more effective fire preventionand surveillance, it is essential topronotea better understanding of the causes of forest fires.

There have been improvements in forest fire prevention over the last few years, especially due to the availability of a greater number of surveillance and detection means and not due to fuel removal.

Iittle attention has been paid to educating and raising awereness among the population, especially when it comes to natural and humanised landscapes with a great enviromental and cultural value. In the state of Santa Catarina conservation units were

${ }^{16}$ It is the Portuguese Goverment's intention in accordance to the National Plan of Forest Protection Against Fire to publish by the end of 2007 a code of Good Practices on Recovery of Bumed Areas, competency of the National Forest Service andprepared jointly with otherpblic entities incluobing the Institute for Nature conservation. 
selected as priority areas for the establishment of PREVFOGO, whereas in Portugal no particularly attention is paid to protectedareas.

In terms of cogperation between Portugal and the state of Santa Catarina within the scope of the prevention and management of fire in protected areas we should point at the participation by members of the Brazilian enviromental police in training sessions heldinPortagel.

In the state of Santa Catarina the intervention in the recovery of bumed areas is not significant, since the first qption has been natural regeneration. In Portugal although the first experiences inloumed area recovery date badk from the 1980s, this type of intervention is still very incipient in theprotectedareas. The experiences following the 2003 fires are very recent, thus it is still early to assess the intervention in order to define and validate the principles and practices of recovery of loumed areas as well as its impacts on nural landscape and on the promotion of fire resilience.

Some managers of protected areas aspire to the elaboration of a code of good practices on bumed area recovery. We should also point at that althagh the recovery of burned areas is not many times regarded as a priority to nature conservation, this topic is an important opportunity for social, economic and enviromental enhancement of the nural landscape and also the cqportunity to tum these areas more resilient toforest fires.

\section{Acknowledgments}

The authors would like to thank the managers of the Portuguese and Brazil 7 ian protected areas who retumed the questionnaires and who have therefore made this studypossible.

\section{References}

Instituto da Conservação da Natureza, Relatório sobre Incêndios Rurais na Rede Nacional de Áreas Protegidas e na Rede Natura 2000, MinisTírIo do Ambiente, do Ordenamento do Território E dO DesenvolvinenIO REgional (MAOTDR), Lisboa, 2006.

Conselho Nacional de Reflorestação, Orientações estratégicas para a recuperação das áreas ardidas em 2003 e 2004, Ministério da Agricultura, do Desenvolvimento Rural e das Pescas, Lisboa, 2005.

Resolução do Conselho de Ministros n. ${ }^{\circ}$ 65/2006 de 26 de Maio de 2006, DIÁRIO DA REPÚBLICA $N^{\circ}$ 102, I SERTE-B 3511.
IRAMA (Instituto Brasileiro do Meio Ambiente e dos Recursos Naturais Renováveis) - Unidades de conservação, 2006, available at http:// www. Ibama.gov. br.

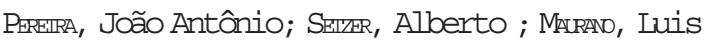
Eduardo (2004) - "Visão atual do sistema de monitoramento de fogo na América do Sul". In: VI seminário de atualização em Sensor Remoto de informações Geográficas aplicadas à Engenharia florestal- Aplicaçães de Ceotecnologia na Engenharia Florestal. INPE, São jose das Campos, SP, at 2004, pp. 245 a 254.

SAnnos, Juliana Ferreira; SoApes, Viana Ronaldo; BMISIA, Antonio Carlos (2006) - "Perfil das incendios Florestais no Brasil em áreas protegidas no período de 1988 a 2002". Floresta, Aritiba, v.36 n . 1 Jan/ Abr 2006, pp. 93 a 100.

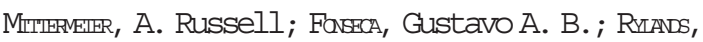
Anthony B. e Brandar (2005) - "Katrina. Uma breve história da conservação da biodiversidade no Brasil" . Megadiversidade, v. $1 n^{\circ} 1$, Jil. 2005, pp. 14 -21.

Mefrires, Rodrigo (2006) - Evolução das Tipologias e Categorias de Áreas Protegidas Ambiente \& Sociedade, ed. Nepam- Unicamp, vol. IX n 1 jan/fev. 2006 p 41-64. Campinas.

Perrosa, Fantina Tedim (2007) - "The Management of Forest Fires in Protected Areas in Portugal", oral presentation at GEOMED 2007 - International Stmposium on Geography, 5- 8 June, Kemer Antalya, Turkey.

PerrosA, Fantina Tedim; PIrks, João (2007) - "Forest Fire Prevention in the Peneda-Geres National Park (Northem Portugal)", oral presentation at GEONED 2007 - Intemational Symposium on Geography, 5- 8 June, Kemer Antalya, Turkey.

Parrosa, Fantina Tedim; Herravan, Maria Lúcia (2007) - "Forest Fires in ProtectedAreas in Portugal and in the state of Santa Catarina (Brazil) . Comparative Analysis of Policies of Prevention and Recovery of Bumed Areas", oral presentation at Wildfire 2007 - 4th Intemational Wildland Fire Conference, 13-17 May, Seville, Spain.

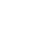

